\title{
A NEW TRANSFER METHOD FOR STUDYING FOSSIL PLANTS
}

\section{BY \\ William C. Darrah}

The Microscopic study of fossil plants has made many great advances since Henry Witham published his histological investigation of several fossils from Great Britain in 1833. His study comprised notes on twelve species prepared by the thin section method, by which translucent sections could be ground from slices sawn from petrified specimens. This method has been in general use for more than a century.

More recently translucent sections have been prepared by the peel method. A specimen is etched with a suitable acid in order to dissolve the inorganic matrix and expose the carbonized portions of the preserved plant structures. Following this step, a solution of nitrocellulose in butyl acetate is poured over the etched surface. After the nitrocellulose has dried it can be peeled off, pulling with it a nearly perfect replica of the preserved structure.

The thin section can be subjected to magnifications from 100 to 250 times, but the thickness of the glass slide, the thin section of the fossil, and the cover glass collectively prevent the use of higher magnifications - at least with transmitted light. A ground section is almost always more than one cell thick.

The nitrocellulose peel, in contrast, may be so prepared that the thickness of fossil is from one to three micra, frequently much less than one cell in thickness. However, the thickness of the nitrocellulose is relatively great. Even so, magnifications greater than 500 times are usually permitted, and occasionally excellent photographs can be made at magnifications of 1200 times. 
One of the great problems attendant upon the study of fossil plants with structure preserved is the difficulty involved in using high magnifications. The use of oil immersion objectives has hitherto been impractical.

Several months ago, my colleague, Doctor A. Orville Dahl suggested the possibility of preparing a peel and subsequently freeing the occluded plant structures by redissolving the nitrocellulose. With this purpose in mind, I tried a number of procedures on various types of fructifications with encouraging results.

A peel containing spores or pollen grains is carefully cropped with scissors and the selected portion is set aside for the transfer of the spores or pollen. Then a glass slide is thoroughly cleaned and moistened with a droplet of albumen (egg-white). The slide is air dried in a dust-free place for twenty minutes and then the peel is impressed in the albumen. The glass slide with the peel adhering to it is placed in a container of butyl acetate and is permitted to stand until all of the nitrocellulose has been dissolved. This is usually accomplished in three or four hours. When this transfer of the spore or pollen grain has taken place, that is, the body is now imbedded in the albumen instead of the nitrocellulose, the slide is removed from the solvent and is gently dipped into butyl alcohol. The albumen can then be completely dehydrated with absolute ethyl alcohol, and the fossil quickly covered with balsam and a cover glass. Such a permanent mount can be studied in the same manner as a similar preparation of parts of extant plants.

With this new tool, paleobotanists may be able to find gametophytes among those extinct ferns which are supposed to have been endosporal in development, and to investigate the male gametophytes of the early seed plants. 


\section{$2 \mathrm{BHL}$ Biodiversity Heritage Library}

Darrah, William C . 1938. "A new Transfer Method for studying Fossil Plants." Botanical Museum leaflets, Harvard University 7(2), 35-36.

https://doi.org/10.5962/p.295126.

View This Item Online: https://www.biodiversitylibrary.org/item/31894

DOI: https://doi.org/10.5962/p.295126

Permalink: https://www.biodiversitylibrary.org/partpdf/295126

\section{Holding Institution}

Missouri Botanical Garden, Peter H. Raven Library

\section{Sponsored by}

Missouri Botanical Garden

\section{Copyright \& Reuse}

Copyright Status: Public domain. The BHL considers that this work is no longer under copyright protection.

This document was created from content at the Biodiversity Heritage Library, the world's largest open access digital library for biodiversity literature and archives. Visit BHL at https://www.biodiversitylibrary.org. 